\title{
Implementasi Profit and Loss Sharing Petani Padi Ditinjau dari Perspektif Ekonomi Islam
}

\author{
Julio Basuki Herlangga \\ Program Doktor UIN Sunan Kalijaga Yogyakarta \\ Email korespondensi: julio.basuki@ gmail.com
}

\begin{abstract}
Abstrak
In Kaibeso, there is a profit sharing system in agriculture done among paddy farmers, and it is called paron system. Paronsystem is used by Kadibeso people as a way to share the work profit between farmers and rice field owners. This system has been preserved among farmers, especially those in Kadibeso village. This system,which is similar to profit sharing system in Islamic economy, becomes the accounting system for capital owners (rice field) and the cultivators. In Islamic economy system, this cooperation between capital owners (rice field) and the cultivators is called Muzara'ah and Mukhabarah.The metod used in this research is qualitative method- a research done to understand the phenomena experienced by the subject of the research such as behavior, perception, mitivation, and action. The data used in this reseacrh consist of primary and secondary data.Paron system is line with Islamic economic system because it does not lease ice field but give the right to farmers to cutivate. It is already in line with Al-Quran and Haditd.
\end{abstract}

Keyword : Paron, Islamic economy, Muzara'ah, Mukhabarah.

Saran sitasi: Herlangga, J. B. (2021). Implementasi Profit and Loss Sharing Petani Padi Ditinjau dari Perspektif Ekonomi Islam. Jurnal Ilmiah Ekonomi Islam, 7(02), 693-703. doi: http://dx.doi.org/10.29040/jiei.v7i2.2432

DOI: http://dx.doi.org/10.29040/jiei.v7i2.2432

\section{PENDAHULUAN}

Banyak provinsi di Indonesia yang menjadi penyumbang PDB salah satunya adalah Provinsi Daerah Istimewa Yogyakarta. Menurut Badan Pusat Statistik pada tahun 2015 luas panen tanaman padi di Daerah Istimewa Yogyakarta adalah 154.807 Hektar menurun dari tahun 2014 sebesar 158.903 Hektar. Produktivitas padi di Daerah Istimewa Yogyakarta adalah 59,64 Ton naik sebesar 1,77\% dari tahun 2014. Hasil tersebut menunjukan bahwa usaha pertanian di daerah Istimewa Yogyakarta didominasi oleh rumah tangga (Badan Pusat Statistik : 2016)

Hal ini juga terlihat pada pedukuhan Kadibeso yang sebagian besar masyarakatnya bekerja sebagai petani padi. Kadibeso berada di desa Sabdodadi Kecamatan Bantul, Kabupaten Bantul, Provinsi Daerah Istimewa Yogyakarta. Kadibeso mempunyai luas lahan pertanian seluas 33 Hektar dengan sekitar 200 masyaratnya bekerja sebagai buruh tani. Jumlah kepala keluarga di pedukuhan Kadibeso sejumlah 325 KK (wawancara dengan kepala dukuh).

Dalam kehidupan masyarakat Kadibeso terdapat sistem bagi hasil dalam pertanian yang sering dilakukan oleh petani padi, masyarakat Kadibeso biasa menyebutnya dengan sistem paron. Sistem paron digunakan masyarakat Kadibeso sebagai sarana pembagian hasil kerjasama antara petani dengan pemilik sawah. Sistem paron telah lama dan telah membudidaya di kalangan petani khususnya di pedukuhan Kadibeso.

Sistem paron yang mendekati konsep bagi hasil dalam ekonomi Islam ini menjadi sistem perhitungan antara pemilik modal (sawah pertanian) dengan penggarap. Pemilik sawahbiasanya meminta kepada penggarap untuk mengelola sawahnya hingga musim panen tiba. Setelah musim panen tiba kemudian padi yang sudah menjadi gabah dijual yang kemudian hasil dari penjualan tersebut di bagi hasilkan 50:50 antara pemilik sawah dengan penggarap.

Dalam pelaksanaan bagi hasil dengan sistem paron jika mengalami keuntungan akan dibagi dengan jumlah yang sama antara pemilik dengan penggarap jika terjadi kerugian kadang-kadang sering terjadi perdebatan antara pemilik sawah dengan penggarap, karena penggarap tidak hanya mengelola sawah tersebut dengan tenaganya saja akan tetapi penggarap 


\section{Jurnal Ilmiah Ekonomi Islam, 7(02), 2021, 694}

juga membelikan pupuk dan obat pengusir hama secara rutin. Setiap usaha pasti memiliki risiko tertentu begitu juga dengan bertani padi yang memiliki risiko gagal panen akibat kondisi cuaca, bencana alam, serta serangan dari hama.

Dalam ekonomi Islam bagi hasil (profit and loss sharing) sering disebut dengan istilah al-mudharabah yang menjadi landasan dasar bagi operasional bank Syariah. Menurut M. Yazid Afandi mudhrabah (mudlarabah) adalah salah satu bentuk kerja sama antara pemilik modal (shahib al-mal) dan pedagang atau orang yang mempunyai keahlian untuk melakukan usaha bersama.

Pemilik modal menyerahkan modalnya kepada pengusaha/pedagang untuk usaha tertentu. Jika dari usaha tersebut mendapatkan keuntungan maka dibagi bersama sesuai kesepakatan. Apabila terjadi kerugian maka kerugian ditanggung oleh pemilik modal, dan pengusaha tidak berhak atas upah dari usahanya (Afandi, 2009:101).

Mudharabah mempunyai arti berjalan di atas bumi yang bisa dinamakan berpergian. Secara terminologi Mudharabah adalah kontrak perjanjian antara pemilik modal dan pengelola untuk digunakan untuk aktivitas yang produktif dimana keuntungan dibagi dua antara pemodal dan pengelola modal. Kerugian jika ada ditanggung oleh pemilik modal, jika kerugian itu terjadi dalam keadaan normal (Mardani, 2012:194).

Secara teknis, mudharabah adalah akad kerjasama usaha antara dua pihak, di mana pihak pertama bertindak sebagai pemilik dana (shahibul maal) yang menyediakan seluruh modal $100 \%$, sedangkan pihak lainya sebagai pengelola dana (mudharib). Keuntungan yang didapat dari usaha yang dijalankan dibagi menurut kesepakatan ada awal perjanjian (Djuwairi, 2008:224).

Menurut Syafi'i Antonio bagi hasil (profit and loss sharing) terdapat juga pada pertanian yang biasa disebut dengan istilah al-Muzara'ah. Al-Muzara'ah adalah kerja sama pengolahan pertanian antara pemilik lahan dan penggarap, dimana pemilik lahan pertanian memberikan lahan pertanian kepada si penggarap untuk ditanami dan dipelihara dengan imbalan bagian tertentu (persentase) dari hasil panen (Antonio, 2001:99).

\section{METODOLOGI PENELITIAN}

Metode yang digunakan dalam penelitian ini adalah meode kualitatif yang bermaksud untuk memahami fenomena masalah, misalkan perilaku, persepsi, motivasi, dan tindakan. Pengambilan sampel sumber data dilakukan secara purposive dan snowball. Sedangkan teknik pengumpulan data dilakukan dengan trianggulasi, analisis data bersifat induktif/kualitatif, dan hasil penelitian kualitatif lebih menekankan makna daripada generalisasi.

Penelitian ini diawali dengan survey langsung, dengan dasar tersebut maka diharapkan memperoleh gambaran secara langsung mengenai implementasi profit and loss sharing dengan sistem paron yang ada di pedukuhan Kadibeso.

Lokasi penelitian adalah di pedukuhan Kadibeso kecamatan Bantul, kabupaten Bantul, DIY. Sedangkan sumber dan jenis data yang digunakan yaitu menggunakan data primer yang didapat dengan cara interview/wawancara terstruktur kepada petani padi yang menggunakan sistem paron. Data sekunder berupa dokumen data penilaian petani padi yang menggunakan sistem paron.

Teknik pengumpulan data dimulai dengan perencanaan,pengumpulan data, pengumpulan data dasar, pembumpulan data penutup dan melengkapi.

\section{PEMBAHASAN}

\section{a. Gambaran Sistem Bagi Hasil (Paron)}

Pedukuhan Kadibeso mempunyai luas lahan pertanian seluas 3,3 Ha yang menyebabkan mayoritas masyarakat di pedukuhan kadibeso bekerja sebagai petani padi. Petani padi pada hal ini adalah pemilik sawah maupun buruh tani atau penggarap sawah. Pertanian di Pedukuhan tersebut memegang peranan yang sangat penting mengingat masih rendahnya taraf pendidikan pada pedukuhan tersebut. Selain itu kurangnya skill dan bantuan dari pemerintah desa juga menyebabkan masyarakat yang berada di Pedukuhan Kadibeso tidak mempunyai pilihan lain kecuali sebagai petani padi.

Pedukuhan Kadibeso belum terdapat lapangan pekerjaan yang cukup untuk menyerap tenaga kerja dengan tingkat pendidikan lulusan SMP dan SMA. Hal ini berbeda dengan Pedukuhan Manding yang terdapat sentra industri kerajinan kulit yang mampu menyerap banyak tenaga kerja yang tidak mempunyai ketrampilan khusus.

Pemilik sawah adalah seseorang yang mempunyai satu atau lebih lahan pertanian (sawah). Pertanian di Pedukuhan Kadibeso dalam pengerjaanya masih bersifat tradisional. Padi yang sudah siap panen pada umumnya menggunakan mesin untuk 


\section{Jurnal Ilmiah Ekonomi Islam, 7(02), 2021, 695}

memisahkan padi dengan batangnya namun di pedukuhan kadibeso masih menggunakan secara manual yaitu dengan cara di pukul ke bambu yang memang sudah di buat sebelumnya oleh penggarap. Pemisahan padi dengan batangnya biasa di sebut dengan istilah gepyok.

Sedangkan yang dimaksud penggarap adalah seseorang yang tidak mempunyai sawah tetapi bersedia untuk mengelola lahan pertanian (sawah) milik orang lain. Penggarap sawah biasanya membagi menjadi tiga tahapan dalam pengerjaanya. Tahapan pertama biasanya di sebut dengan istilah tandur. Tandur adalah penanaman bibit padi dengan menggunakan bilah bambu sebagai pengukur jarak. Tandur biasanya di kerjakan oleh empat orang. Tahapan kedua adalah ngerabok. Ngerabok adalah penyemprotan atau pemberian pupuk yang dilakukan setelah padi berusia satu minggu dan dilakukan berulang-ulang minimal 2 kali dalam satu bulan. Tahapan terakhir adalah gepyok. Gepyok adalah pemisahan antara batang padi dengan benih padi atau biasa disebut dengan gabah.

Bagi hasil dalam lahan pertanian yang di lakukan oleh masyarakat Pedukuhan Kadibeso adalah mengguankan sistem paron.

Menurut Mardiwiyono (80 Tahun) penggarap sawah mengatakan bahwa :

"Paron niku maro sek kagungan sawah separih sik nanem separih. Nggih biasane kulo angsal 3 juta niku kulo 1,5 juta pak Gito ingkang gadah sawah 1,5 juta. Misale enten gagal panen sek gadah sawah mboten angsal nopo-nopo. Sek buruh nggih mboten angsal nopo-nopo neng pun rugi soale pun medalke biaya kathah kagem tumbas rabok. Biasanipun kulo tumbas rabok telas Rp 700.000”. (Paron itu maro yang mempunyai sawah sebagian yang mengelola sebagian. Biasanya saya mendapat 3 juta dari 3 juta itu saya mendapatkan 1,5 juta dan pak Gito sebagai yang mempunyai sawah mendapatkan 1,5 juta. Misalnya ada gagal panen yang punya sawah tidak dapat apa-apa, yang mengelola juga tidak dapat apa-apa tetapi rugi soalnya sudah mengeluarkan biaya untuk keperluan membeli pupuk.

Menurut Hari Martuti (40 Tahun) mengatakan bahwa :
"Paron itu ya pokoknya padi panen dapet 12 karung masing-masing 6 karung. Kalau kemaren dari $500 \mathrm{~m} 2$ separonya saya dapet 3,5 karung. Biasanya yang dibagikan itu berasnya bukan uang hasil panenanya setelah diual,untuk biaya-biaya semua ditanggung oleh penggarapnya pokoknya yang punya sawah tinggal terima bersih. jika terjadi kerugian maka yang paling rugi adalah penggarap soalnya sudah mengeluarkan biaya".

Pelaksanaan bagi hasil di Pedukuhan Kadibeso dengan sistem paron adalah pembagian hasil pertanian yang dibagikan dengan jumlah yang sama. Misalkan dari hasil panen mendapatkan 12 karung maka di bagi secara rata 6 karung untuk penggarap dan 6 karung utuk pemilik sawah. Biaya yang muncul dalam proses pengelolaan lahan pertanian meliputi benih padi, pupuk, dan alat pertanian di tanggung oleh penggarap. Jika terjadi kerugian (gagal panen) maka pemilik sawah tidak mendapatkan apapun, sedangkan penggarap juga tidak mendapatkan hasil walaupun sudah mengeluarkan biaya.

\section{b. Perjanjian Bagi Hasil Dengan Menggunakan Sistem Paron}

Dalam perjanjian bagi hasil dengan menggunakan sistem paron di Pedukuhan Kadibeso biasanya masyarakat hanyamenggunakan perjanjian secara lisan hal ini dilakukan secara turun temurun. Dalam sistem paron pemilik sawah lah yang biasanya mencari penggarap untuk meminta menggarap sawahnya.

Seperti halnya yang diungkapkan oleh Madyo Pawiro (75 Tahun) menyatakan sebagai berikut:

"Sistem paron kuwi ono wes ket jaman kakek ninek,wes ora kelingan nek kiro-kiro yo tahun 1951.Biasane yo sek golek yo sek duwe sawah, hake sek duwe sawah akon sek garap, sek garap yo saguh.paron kuwi ora eneng berjanjen nek wes eleh yo pasrah, nek wes ora cocok jaluk di tanduri wong liyo". (Sistem paron itu sudah ada dari aman nenek moyang, sudah lupa kira-kira dari tahun 1951. Biasanya yang mencari yang mempunyai sawah, haknya yang punya sawah mencari penggarap, penggarap juga bersedia.paron itu tidak ada perjanjianya kalau penggarap sudah bosan ya pasrah, tetapi kalau pemilik sawah sudah tidak cocok minta untuk di kelola oleh orang lain). 


\section{Jurnal Ilmiah Ekonomi Islam, 7(02), 2021, 696}

Setelah wawancara lebih mendalam mengenai alasan mengapa tidak menggunakan perjanjian secara tertulis madyo pawiro mengungkapkan:

"nak go tulis menulis ki mengko kewuhan luweh repot,okeh sek di urus. Lagian sek garap sawah kan uwes kulino wes koyo sedulur dadi yo percoyo-percoyo wae." (jika menggunakan perjanjian secara tertulis banyak yang di urus dan repot. Penggarap sawah juga sudah di anggap seperti keluarga sendiri jadi percaya saja)

Dalam Undang-undang No 2 tahun 1960 Tentang Bagi Hasil Pertanian, pada pasal 3 berbunyi "Semua perjanjian bagi hasil harus di buat oleh pemilik dan penggarap sendiri secara tertulis di hadapan Kepala Desa atau daerah yang setingkat dengan itu tempat letaknya tanah yang bersangkutan, selanutnya dalam undang-undang ini disebut Kepala Desa dengan dipersaksikan oleh dua orang, masing-masing dari fihak pemilik dan penggarap".

Dapat dianalisis dalam pembagian bagi hasil dengan sistem paron di Pedukuhan Kadibeso bertolak belakang antara kenyataan dengan Undang-undang No 2 tahun 1960 Tentang bagi Hasil Pertanian. Masyarakat Pedukuhan Kadibeso banyak yang belum mengetahui tentang adanya peraturan mengenai Bagi Hasil Pertanian yang di atur dalam Undang-undang No 2 1960. Bentuk perjanjian lisan ini berlaku hingga saat ini, walaupun secara lisan tetapi sampai saat ini belum pernah teradi perselisihan hingga sampai alur hukum.

\section{c. Alasan Terjadinya Sistem Paron}

1) Alasan pemilik sawah

Perjanjian bagi hasil dengan sistem paron pada dasarnya terjadi dikarenakan pemilik sawah mempunyai pekeraan lain sehingga tidak mempunyai cukup waktu untuk mengerjakan sawahnya, oleh karena itu pemilik sawah mencari orang yang bersedia menggarap sawahnya dengan sistem paron. Hal ini sesuai dengan yang diungkapkan pemilik sawah Heri Martuti (40 Tahun) menyatakan sebagai berikut :

"Karena saya mempunyai pekerjaan lain mas jadi saya tidak punya waktu untuk bertani. Selain itu menggarap sawah itu uga tidak sembarangan orang bisa mengerjakan harus dapat memilih benih yang bagus dan pupuk yang cocok.maka saya menawarkan sistem paron kepada orang yang mau.

Berdasarkan wawancara dengan Joni (36 Tahun) dan Madyo Pawiro (75 Tahun)

"Karena saya selonya cuma hari minggu saja jadi saya minta tolong sama orang lain. Garap sawah itu ya gak bisa kalau Cuma satu orang tapi saya kalau selo ya ikut ke sawah".

"Aku wes wong tuwo le wes ra kuat meneh nak kon neng sawah,dinggo mlaku we angel". (saya sudah tua mas sudah tidak kuat lagi, untuk berjalan saja susah)

Dapat disimpulkan dari wawancara diatas alasan pemilik sawah melakukan perjanjian dengan sistem paron:

a) Mempunyai pekerjaan lain.

b) Tidak ada waktu untuk menggarap sawahnya.

c) Tidak mempunyai skill yang cukup untuk menggarap sawah.

2) Alasan penggarap sawah

Pada dasarnya penggarap melakukan bagi hasil pertanian dengan sistem paron dikarenakan tidak adanya pekerjaan lain dan tidak mempunyai lahan garapan sehingga tidak dapat memenuhi kebutuhan keluarganya. Sehingga penggarap tidak mempunyai pilihan lain kecuali menggarap sawah milik orang lain. Hal ini seperti yang di ungkapkan poniran (62 tahun) sebagai berikut:

"Keuntungane enten sistem paron niku kulo dados gadah pengahasilan ge nyambung urip lan gadah kesibukan.kulo purun maro soale geh pripun maleh kulo isane geh namung buruh tandur". (Keuntungan dari sistem paron saya jadi mempunyai penghasilan untuk menyambung hidup dan mempunyai kesibukan.saya mau maro dikarenakan yang bisa saya kerjakan adalah sebagai penggarap sawah

Peneliti menanyakan lebih dalam mengenai selain bertani skill dan pendidikan yang dimiliki oleh bapak Poniran: 
Jurnal Ilmiah Ekonomi Islam, 7(02), 2021, 697

"sek kulo sageti gih namung tandur niku paling gih kaleh buruh kongkonan. Nek enten sek nyuwun tulung ngresiki plataran nopo kon ngurus tanduran. Kulo namung lulusan SMP"(yang saya bisa hanya menggarap sawah sam menjadi orang suruan semisal ada yang minta tolong untuk membersihkan halaman taua menyirami/merawat tanaman).

Sedangkan Poniyem (75 Tahun) mengatakan :

"yo piye yo le nak ditakoni alasane yo tekmene ket biyen yo wes gaweane ngono kuwi. Lagian yo wes kebacut berjanji karo sek duwe sawah". (ya kalau di tanya alasannya dikarenakan dari dulu memenag sudah bertani. Selain itu juga sudah terlanjur ada perjanjian dengan pemilik sawah)

Jadi (35 Tahun) mengatakan:

"Ya karena tidak punya sawah, jadi saya garap sawah milik orang lain. Walaupun saya juga mempunyai ekerjaan lain tetapi hasil dari garap sawah milik orang lumyan bisa buat tambah-tambah".

Dapat disimpulkan dari wawancara diatas alasan penggarap sawah melakukan perjanjian dengan menggunakan sistem paron:

a) Tidak mempunyai pekeraan lain

b) Tidak mempunyai sawah

c) Karena untuk mencukupi ekonomi keluarga

d) Tidak memiliki skill yang cukup

\section{d. Pembagian Hasil Penen dan Kerugian dengan} Menggunakan Sistem Paron di Pedukuhan Kadibeso

Pembagian hasil pertanian dengan sistem paron menurut masyarakat Pedukuhan Kadibeso sudah adil dikarenakan dengan adanya sistem paron masyarakat kurang mampu menjadi terbantu dalam segi ekonominya. Selain itu dikatakan adil dikarenakan jika menyewa tanah kas desa mengeluarkan biaya yang cukup besar tidak sebanding jika menggunakan sistem paron.
Berdasarkan wawancara dengan Surami (52 Tahun) mengatakan bahwa:

"Gih nak rumangsa kulo gih adil wong nak nyewo tanah kas niku gih larang, gek niku gih karepe sing garap". (kalau menurut saya sudah adil dikarenakan jika menyewa tanah kas desa itu mahal. Lagian yang minta untuk paron itu dari ihak penggarap. (wawancara dengan Surami, pemilik sawah, tanggal 21 Maret 2016)

Dalam sistem paron jika terjadi kerugian yang sangat dirugikan adalah penggarap. Penggarap dalam satu kali musim panen mengeluarkan setidaknya Rp.700.000 - Rp.1.000.000 untuk mengelola sawah tersebut. Penggarap mengeluarkan biaya tersebut untuk pembelian benih padi, pupuk,dan alat pertanian yang di gunakan untuk mengelola sawah tersebut. Biaya yang sudah dikeluarkan jika terjadi gagal panen maka pemilik sawah tidak menanggung biaya yang sudah dikeluarkan oleh penggarap walaupun pemilik sawah tidak mendapatkan hasil pertanianya dikarenakan gagal panen. Meskipun penggarap sudah menanggung biaya tetapi penggarap juga tidak mendapatkan hasil dari sawah yang dia kelola. Sistem paron memang terlihat tidak adil, namun sampai dengan saat ini belum pernah terjadi perselisishan atau kesalah pahaman antara pemilik sawah dengan penggarap jika terjadi gagal panen penggarap tetap bersedia untuk menggarap sawah di musim berikutnya.

Seperti hasil wawancara dengan salah satu penggarap, Yatin (78 tahun) menyatakan:

"Nek misal e gagal panen yo sek paling rugi yo aku le, aku garap sawah $300 \mathrm{~m} 2$ kuwi ngenteke biaya Rp.750.000 an dinggo werno-werno yen gagal panen sek duwe sawah ora oleh opo-opo sek garap yo ora oleh opo-opo neng aku rugi duwit Rp.750.000 an mau seng wes tak toke dinggo werno-werno mau.intine sek duwe sawah ora ngetoke duit". (Jika terjadi gagal panen maka yang paling di rugikan saya mas,saya mengelola sawah $300 \mathrm{~m} 2$ itu menghabiskan biaya Rp.750.000 an untuk keperluan sawah jika gagal panen pemilik sawah tidak mendapatkan hasil panen dan penggarap juga tidak mendapatkan apa-apa tetapi saya sudah rugi uang sebesar Rp.750.000 an tadi yang sudah saya keluarkan untuk keperluan sawah tadi.intinya pemilik sawah tidak mengeluarkan uang). 


\section{Jurnal Ilmiah Ekonomi Islam, 7(02), 2021, 698}

Dari pernyataan diatas, dapt disimpulkan bahwa praktik bagi hasil dengan menggunakan sistem paron jika teradi kerugian maka yang menanggung biaya yang sudah dikeluarkan adalah penggarap sawah meskipun antara pemilik dan penggarap sawah samasama tidak mendapatkan hasil dari pertanianya.

Sistem paron yang sudah berkembang di Pedukuhan Kadibeso adalah sistem satu-satunya yang digunakan masyarakat dalam bagi hasil pertanianya. Hal ini sesuai dengan yang di ungakapkan Jadi (35 Tahun) mengatakan bahwa:

"Selain sistem paron tidak ada sistem yang digunakan masyarakat Pedukuhan Kadibeso dalam pembagian pertanianya".

Berdasarkan wawancara dengan Poniyem (75 tahun) mengatakan:

"Mboten enten mas, entene gih namung paron

niku”. (Tidak ada mas, yang ada hanya sistem paron itu".

Sama halnya dengan yang di ungkapkan oleh Joni (36 Tahun) yang menyatakan:

"Setau saya ya cuma paron atau maro itu.

Dari pernyataan beberapa responden dapat disimpulkan bahwa sistem paron adalah sistem bagi hasil satu-satunya yang digunakan masyarakat Pedukuhan Kadibeso dalam bagi hasil pertanianya.

\section{e. Kendala Petani Padi Dalam Pengelolaan Lahan Pertanianya}

Padi adalah tanaman yang rentan dengan pengaruh cuaca dan ketersediaan air. Faktor angin juga berpengaruh dalam proses pengelolaan tanaman padi. Hal ini sama dengan yang diungkapkan Heri Martuti (40 Tahun) bahwa:

"Kesulitan dalam menggarap sawah itu ya faktor angin mas,seperti -akhir ini anginya kencang itu petani ya agak sulit.padi yang belum ada isinya kena angin jadi pada kopong atau gabuk".

Sama halnya dengan yang di ungkapkan oleh Jadi (35 Tahun) yang menyatakan:

"Yang paling susah itu untuk pengairanya mas,sebagai petani suka mencari air hingga malam hari".

\section{f. Sistem Paron Ditinjau Dari Ekonomi Islam}

Dari hasil penelitian yang didapatkan dari wawancara terhadap pemilik sawah dan penggarap sawah mengenai praktik bagi hasil petani padi yang ditinjau dari konsep Ekonomi Islam di Pedukuhan
Kadibeso Desa Sabdodadi Kecamatan Bantul Kabupaten Bantul Provinsi Daerah Istimewa Yogyakarta. Dalam pembahasan ini penulis akan membahas hasil dari penelitian yang berkenaan tentang praktik bagi hasil petani padi yang ditinau dari konsep Ekonomi Islam di Pedukuhan Kadibeso Desa Sabdodadi Kecamatan Bantul Kabupaten Bantul Provinsi Daerah Istimewa Yogyakarta dan dampak terhadap ekonomi masyarakat di Pedukuhan Kadibeso.

Praktik bagi hasil masyarakat dalam pertanian di Pedukuhan kadibeso menggunkan sistem paron. Sistem paron adalah sistem perhitungan antara pemilik modal (sawah pertanian) dengan penggarap. Pemilik sawahbiasanya meminta kepada penggarap untuk mengelola sawahnya hingga musim panen tiba. Setelah musim panen tiba kemudian padi yang sudah menjadi gabah di bagi hasilkan 50:50 antara pemilik sawah dengan penggarap. Sistem paron telah dilakukan secara turun-temurun oleh masyarakat Pedukuhan Kadibeso.

Berkaitan dengan sistem bagi hasil tanah pertanian dengan menggunakan sistem paron telah berlangsung sejak lama dan masih berlaku hingga sekarang. Penggarap mengupayakan agar sawah garapannya memberikan hasil yang sebaik-baiknya, namun dalam realitanya terdapat banyak kendala seperti faktor alam. Penggarap harus bersungguhsungguh dalam pengerjaanya agar memperoleh hasil yang baik.

Dalam Islam sudah diatur mengenai bagi hasil sesuai dengan konsep Islam, yang boleh dilakukan dan yang dilarang dalam Islam. Hal ini dapat dilihat dari beberapa hadis berikut:

Dari Ibnu Umar: "Sesungguhna Nabi SAW. Telah memberikan kebun kepada penduduk khaibar agar dipelihara oleh mereka dengan perjanjian mereka akan diberi sebagian dari penghasilan, baik dari buah - buahan maupun dari hasil pertahun (palawija)" (H.R Muslim)

Berkata Rafi' bin Khadij: "Diantara Anshar yang paling banyak mempunyai tanah adalah kami, maka kami persewakan, sebagian tanah untuk kami dan sebagian tanah untuk mereka yang mengerjakannya, kadang sebagian tanah itu berhasil baik dan yang lain tidak berhasil, maka oleh karenanya Raulullah SAW. Melarang paroan dengan cara demikian (H.R. Bukhari) 


\section{Jurnal Ilmiah Ekonomi Islam, 7(02), 2021, 699}

“Diriwayatkan oleh Râfi' bin Khudaij R.A., ia berkata : Suatu ketika ketika kami sedang mengadakan pengolahan lahan dengan bagi hasil tertentu (mukhâbarah), kemudian datanglah kepadanya sebagian dari keluarga pamannya dan mengatakan : Sesungguhnya Rasulullah Saw. melarang akan sesuatu perkara yang sebenarnya bermanfaat bagi kami, dan sungguh ketaatan atas Allah Swt. Dan Rasul-Nya adalah lebih bermanfaat bagi kami. Lalu kami mengatakan: dan apakah perkara itu? Ia berkata: Rasulullah Saw. bersabda : Barang siapa yang memiliki lahan hendaklah ia menanaminya atau memberikannya kepada saudaranya untuk ditanami. Dan janganlah ia menyewakan sepertiganya, atau seperempatnya, dan tidak juga dengan makanan." (H.R. Muslim dan Abu Dawud)

Dari jalan Rafi' bin Khadij, ia berkata: "Kami kebanyakan pemilik tanah di Madinah melakukan muzâra'ah, kami menyewakan tanah, satu bagian daripadanya ditentukan untuk pemilik tanah maka kadang-kadang si pemilik tanah itu ditimpa suatu musibah sedang tanah yang lain selamat, dan kadangkadang tanah yang lain itu ditimpa suatu musibah, sedang dia selamat, oleh karenanya kami dilarang. (H.R. Bukhari).

"Dari Hanzhalah bin Qais dari Rafi' bin Khadij, dia berkata, pamanku telah menceritakan kepadaku bahwasanya mereka menyewakan tanah pada zaman Nabi dengan apa yang tumbuh dari saluran-saluran air atau sesuatu yang telah dikecualikan pemilik tanah, kemudian Nabi shollallohu ,'alaihi wa sallam melarang hal itu. Aku bertanya kepada Rafi', bagaimana bila dengan dinar dan dirham?, maka Rafi' menjawab, tidak mengapa menyewa tanah dengan dinar dan dirham.(HR Bukhari).

Dari Urwah ibnu Zubair berkata, berkata Zaid bin Tsabit: "Semoga Allah mengampuni Rafi' ibnu Khadij. Demi Allah, Aku lebih mengetahui hadits daripada ia. Rasulullah saw melarang menyewakan tanah, dikarenakan pada suatu hari ada dua orang yang bunuh membunuh sebab masalah penyewaan tanah, maka dari itu beliau bersabda: "Jika kamu bertengkar seperti ini, janganlah kamu menyewakan tanah"Rupanya ia hanya mendengar sabda beliau: "Janganlah kamu menyewakan tanah”.(H.R.An Nasa'i)

Dari beberapa hadis di atas dapat disimpulkan bahwasanya Islam membolehkan kerjasama dalam bidang pertanian dengan sistem bagi hasil. Sedangkan hadis yang melarang akad Muzaraah (kerjasama dalam pertanian) adalah ketika pemilk sawah menyewakan sebagian tanahnya kepada penggarap atau membagi atas tanah garap terlebih dahulu Hal ini sesuai dengan yang disampaikan oleh Ahmad Sarwat yang menyatakan bahwa muzara'ah yang diharamkan semisal, dari luas $1.000 \mathrm{~m}$ persegi yang disepakati, pemilik lahan menetapkan bahwa dia berhak atas tanaman yang tumbuh di area $400 \mathrm{~m}$ tertentu. Sedangkan tenaga buruh tani berhak atas hasil yang akan didapat pada $600 \mathrm{~m}$ tertentu. Hal ini dianggapgharar karena terdapat ketidak jelasan pada bagi hasil yang akan diperoleh. Misalkan, dari lahan $1.000 \mathrm{~m}$ saat terjadi panen kemudian lahan $400 \mathrm{~m}$ terjadi gagal panen maka pemilik lahan mengalami kerugian begitu juga sebaliknya apabila yang terjadi gagal panen pada lahan $600 \mathrm{~m}$ maka pihak penggaraplah yang dirugikan (Sarwat, 2009:120).

Selain itu dalam pembahasan muzara'ah terjadi perbedaan pendapat para ulama. Imam Abu Hanifah (80-150 H/699-767 M) dan Zufair ibn Huzail (728-77 M), pakar fiqh hanafi, berpendaat bahwa akad muzara'ah tidak boleh. Alasan Imam Abu Hanifah dan Zufair ibn Huzail adalah hadis yang bersumber dari Tsabit Ibnu adh-Dhahhak:

"Dari Tsabit ibnu Dhahhak bahwasanya Rasulullah Saw. melarang muza'rah “ (H.R. Muslim)

Menurut Imam Abu Hanifah dan Zufair ibn Huzail obyek akad dalam muzara'ah belum ada dan tidak jelas kadarnya, karena yang dijadikan imbalan untuk petani adalah hasil pertanian yang belum ada dan tidak jelas ukuranya, sehingga keuntungan yang akan dibagi tidak jelas(Winarsih, 2008:35).

Sedangkan menurut Abu Yusuf (113-182H/731$798 \mathrm{M}$ ), Muhammad ibn al-Hasan asy-Syaibani (748$804 \mathrm{M})$, keduanya sahabat Abu Hanifah berpendapat bahwa muzara'ah hukumnya boleh, dikarenakan akadnya cukup jelas yaitu menjadikan petani sebagai serikat dalam penggarapan sawah. Akad muzara'ah 


\section{Jurnal Ilmiah Ekonomi Islam, 7(02), 2021, 700}

bertujuan untuk saling membantu antara pemilik sawah dengan penggarap sawah(Winarsih, 2009:37).

Sistem paron yang berkembang dalam masyarakat Pedukuhan Kadibeso adalah sistem dimana pemilik sawah memberikan hak garap sawahnya atau tanahnya kepada penggarap untuk dikelola, keuntungan baru dapat diketahui setelah tiba masa panen dimana keuntungan dibagi sama rata 50:50.

Hal ini berbeda dengan sistem sewa tanah yang maksud dalam hadis diatas pemilik sawah sebelum masa panen tiba sudah mendapatkan keuntungan dari hasil sewa sawah tersebut. Sedangkan jika hasil panen tersebut tidak sesuai dengan harga sewa yang sudah dibayarkan di muka oleh penggarap, maka dalam hal ini terdapat bentuk spekulasi. Spekulasi yang dimaksud adalah jika hasil penen lebih besar dari pada harga sewa sawah maka penggarap akan mendapatkan untung, tetapi jika hasil panen lebih sedikit dari pada harga sewa sawah maka penggarap merugi.

Dalam sistem paron bila terjadi kerugian atau gagal panen maka pemilik sawah tidak menanggung biaya yang sudah dikeluarkan oleh penggarap untuk pengelolaan tersebut. Penggarap dalam menggunakan sistem paron telah mengetahui resiko bila terjadi kerugian atau gagal panen sebelum pemilik sawah menyerahkan sawahnya untuk digarap. Kesepakatan antara pemilik sawah dengan penggarap dilakukan sebelum pemilik sawah menyerahkan sawahnya, dalam hal ini tidak ada unsur paksaan pemilik sawah terhadap penggarap. Hal ini sudah sesuai dengan firman Allah dalam Al-Quran surat An-nisa ayat 29 yang berbunyi:

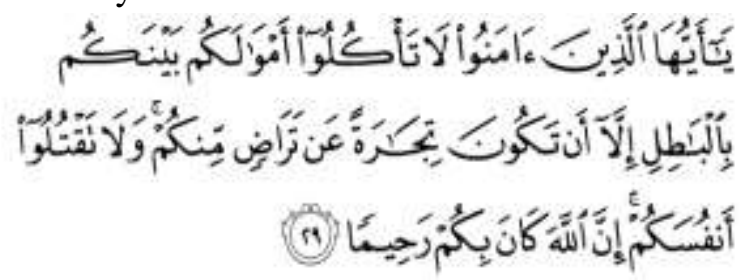

"Hai orang-orang yang beriman, janganlah kamu saling memakan harta sesamamu dengan jalan yang batil, kecuali dengan jalan perniagaan yang berlaku dengan suka samasuka di antara kamu. Dan janganlah kamu membunuh dirimu; sesungguhnya Allah adalah Maha Penyayang kepadamu"

Dari surat diatas dijelaskan bahwa Islam melarang perniagaan atau muamalah dengan cara yang batil. Perniagaan atau mumalah yang diperbolehkan adalah perniagaan yang dimana terdapat perjanjian yang disetujui oleh kedua belah pihak yang bekerja sama atau saling rela. Penjelasan tersebut sesuai dengan kerja sama bagi hasil pertanian menggunakan sistem paron yang terdapat perjanjian antara pemilik sawah dengan penggarap yang kedua belah pihak sudah saling memahami dan menyetujui kerja sama tersebut meskipun secara lisan. Menurut Ahmad Sarwat keuntungan itu harus diketahui jumlahnya. Kalau jumlahnya tidak diketahui, syirkah tersebut dianggap rusak, kecuali kalau terdapat kebiasaan setempat yang sudah merata yang membolehkan pembagian keuntungan dengan cara tertentu, hal itu boleh dilakukan. Keuntungan itu juga harus merupakan sejumlahkeuntungan dengan prosentasi tertentu.Kalau berupa nilaiuang tertentu saja, maka syirkah itu tidak sah. Karena adakemungkinan bahwa kerja sama tersebut hanya menghasilkankeuntungan kadar itu saja, sehingga tidak bisa dibuktikansyirkah dalam keuntungannya (Sarwat, 2009:30).

Menurut Abdullah Jayadi dalam Islam mengenal asas-asas hukum perjanjian. Adapun asas-asas hukum perjanjian sebagai berikut:

\section{Al-Hurrijah (Kebebasan)}

Asas ini merupakan prinsip dasar dalam hukum perjanjian Islam, dalam artian pihak bebas membuat suatu perjanjian atau akad (Freedom of Making Contract). Bebas dalam menentukan obyek perjanjian serta bebas menentukan cara penyelesaian sengketa. Dalam membuat perjanjian tidak boleh ada unsur paksaan, kekhilafan, dan penipuan. Dasar hukum mengenai asas ini tertuang dalam Al-Quran surat Al-Baqarah ayat 256.

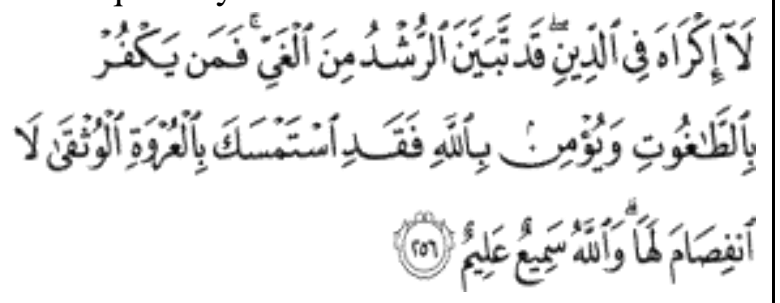

"Tidak ada paksaan dalam (menganut) agama (Islam),sesungguhnya telah jelas antara jalan yang benar dengan jalan yang sesat. Barang siapa ingkar kepada Thaghut dan beriman kepada Allah, maka sesungguhnya dia telah berpegang (teguh) kepada buhul tali yang sangat kuat yang tidak akan putus. Allah Maha mendengar lagi Maha mengetahui” 


\section{Jurnal Ilmiah Ekonomi Islam, 7(02), 2021, 701}

2. Al-Musawah (kesamaan atau kesetaraan)

Asas ini mengandung pengertian bahwa para pihak mempunyai kedudukan (Bergaining Position) yang sama, sehingga dalam menentukan suatu akad atau perjanjian setiap pihak mempunyai kesetaraan atau kedudukan yang seimbang. Dasar hukum mengenai asas ini tertuang dalam Al-Quran surat Al-Hujarat ayat 13.

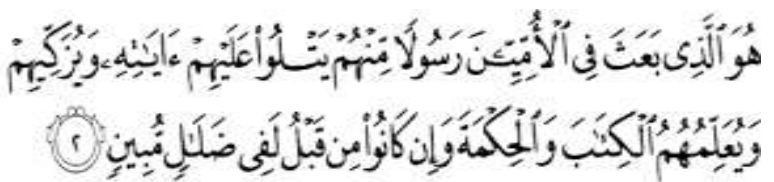

Artinya: Hai manusia, sesungguhnya Kami menciptakan kamu dari seorang laki-laki dan seorang perempuan dan menjadikan kamu berbangsa-bangsa dan bersuku-suku supaya kamu saling kenal-mengenal. Sesungguhnya orang yang paling mulia di antara kamu di sisi Allah ialah orang yang paling taqwa di antara kamu.Sesungguhnya Allah Maha Mengetahui lagi Maha Mengenal”.

3. Al-Adalah (Keadilan)

Pelaksana asas ini dalam suatu perjanjian akad menuntut para pihak untuk melakukan yang benar dalam pengungkapan kehendak dan keadaan, memenuhi semua kewajiban. Perjanjian harus senantiasa mendatangkan keuntungan yang adil dan seimbang.

4. Al-Ridho (Kerelaan)

Asas ini menyatakan bahwa segala transaksi yang dilakukan harus atas dasar kerelaan antara masing-masing pihak, harus didasarkan pada kesepakatan bebas dari para pihak dan tidak boleh ada unsur paksaan, tekanan, penipuan, dan miss-statement. Dasar hukum adanya asas kerelaan dalam pembuatan perjanjian dapat dibaca dalam Al-Quran surat An-Nisa ayat 29.

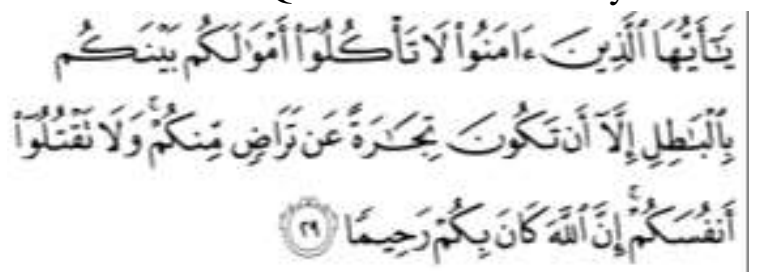

"Hai orang-orang yang beriman, janganlah kamu saling memakan harta sesamamu dengan jalan yang batil, kecuali dengan jalan perniagaan yang berlaku dengan suka samasuka di antara kamu. Dan janganlah kamu membunuh dirimu; sesungguhnya Allah adalah Maha Penyayang kepadamu”
5. Ash-shidq (kebenaran dan kejujuran)

Bahwa didalam Islam setiap orang dilarang melakukan kebohongan dan penipuan. Perjanjian yang didalamnya mengandung unsur kebohongan atau penipuan, memberikan hak kepada pihak lain untuk menghentikan proses pelaksanaan perjanjian tersebut. Dasar hukum mengenai asas Ash-shidq didasarkan pada AlQuran surat Al-Ahzab ayat 70.

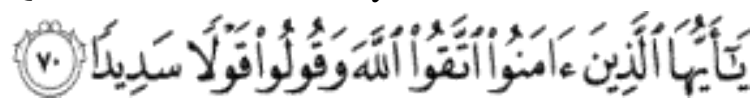

Artinya: Hai orang-orang yang beriman, bertakwalah kamu kepada Allah dan katakanlah perkataan yang benar.

6. Al-Kitabah (tertulis)

Bahwa setiap perjanjian hendaknya dibuat secara tertulis, lebih berkaitan demi kepentingan pembuktian jika dikemudian hari terjadi sengketa. Dalam Al-Quran surat Al-Baqarah ayat 282-283 mengisyaratkan agar akad yang dilakukan benar-benar berada dalam kebaikan bagi semua pihak. Bahkan juga didalam pembuatan perjanjian hendaknya juga disertai dengan adanya saksi-saksi dan prinsip tanggung jawab individu(Jayadi, 2011: 18-20).

Dari asas-asas hukum perjanjian dalam Islam menurut Abdullah Jayadi diatas dapat disimpulkan bahwa pada masyarakat Pedukuhan Kadibeso hukum perjanjian bagi hasil dengan sistem paron tidak sesuai dengan asas-asas konsep perjanjian dalam Islam. Menurut masyarakat Pedukuhan kadibeso perjanjian secara lisan sudah dianggap sah tanpa memandang Undang-Undang Nomor 2 Tahun 1960 Tentang Perjanjian Bagi Hasil.

Pada Pedukuhan Kadibeso konflik antara pemilik dan penggarap sawah tidak pernah terjadi dalam pelaksanaan bagi hasil dengan sistem paron. Hal ini dikarenakan pemiliksawah maupunpenggarap samasama merasa di untungkan dan sama-sama merasa membutuhkan. Selain itu masyarakat di Pedukuhan Kadibeso memiliki rasasaling percaya dan kekeluargaan antara satu dengan yang lain. Sehingga kerjasama dengan sistem ini dapat terus berlangsung. Hal ini dikarenakan antara pemilik sawah dengan penggarap sawah sama-sama memenuhi hak dan kewajibannya. Kewajiban pemilik sawah adalah memberikan sawahnya kepada penggarap untuk di kelola dengan jangka waktu yang telah disepakati. Sedangkan kewajiban penggarap adalah memberikan 
hasil yang sesuai dengan apa yang diperjanjikan dengan kualitas yang maksimal.

Hak pemilik sawah adalah mendapatkan hasil yang maksimal dari hasil panen. Hak penggarap adalah memperoleh perlakuan yang baik dan perlakuan yang adil dari pemilik sawah. Setelah perjanjian selesai maka penggarap wajib mengembalikan sawah kepada pemilik sawah. Begitu juga pemilik sawah tidak dapat meminta sewaktuwaktu sawah yang sudah diserahkan kepada penggarap untuk dikelola tanpa alasan yang jelas.

Dalam realitanya perjanjian bagi hasil dengan menggunakan sistem paron memberikan banyak manfaat pada masyarakat di Pedukuhan Kadibeso. Dari hasil penelitian yang penulis lakukan dengan para petani di Pedukuhan Kadibeso mengatakan bahwa belum pernah terjadi perselisihan antara pemilik dengan penggarap sawah akibat pembagian hasil dengan sistem paron.

Kurangnya sosialisasi menjadi salah satu faktor kurangnya pengetahuan masyarakat mengenai Ekonomi Islam. Sistem paron yang sudah lama berkembang di Pedukuhan kadibeso memberikan dampak positif terhadap masyarakat di Pedukuhan tersebut. Pemilik sawah merasa terbantu dengan adanya sistem paron ini dikarenakan pemilik sawah tidak perlu susah payah menggarap sawah miliknya. Sedangkan bagi penggarap sistem paron meningkatkan perekonomian dalam mencukupi kebutuhan keluarganya.

\section{KESIMPULAN}

Sistem paron adalah sistem perhitungan antara pemilik modal (sawah pertanian) dengan penggarap. Pemilik sawahbiasanya meminta kepada penggarap untuk mengelola sawahnya hingga musim panen tiba. Setelah musim panen tiba kemudian padi yang sudah menjadi gabah di bagi hasilkan 50:50 antara pemilik sawah dengan penggarap. Sistem paron telah sesuai dengan konsep Ekonomi Islam karena sistem paron bukan menyewakan sawah melainkan memberikan hak garap kepada petani penggarap untuk dikelola. Hal ini telah sesuai dengan Al-Quran dan Hadis yang menjelaskan bahwa jika paroan dengan menggunakan sistem sewa maka di khawatirkan sebagian tanah yang disewakan menghasilkan hasil yang baik dan sebagiannya lagi menghasilkan hasil yang tidak baik.

Hal ini tidak sesuai dengan konsep Ekonomi Islam dikarenakan terdapat unsur dzalim dalam kerjasama tersebut. Petani penggarap sebagai penyewa tanah sekaligus pengelola jika terjadi kerugian (gagal panen) tidak mendapatkan hasil dari tanah garapanya bahkan harus membayar sewa tanah kepada pemilik tanah. Sedangkan pemilik tanah jika terjadi kerugian tetap mendapatkan pendapatan dari tanah yang di sewakan terhadap petani penggarap.

Kerugian dalam sistem paron bahwasanya seluruh biaya di tanggung oleh petani penggarap tidak melanggar syariah dikarenakan kedua belah pihak telah sepakat dan saling ridho. Kesepakatan perjanjian dilakukan sebelum pemilik sawah menyerahkan sawahnya kepada penggarap tanpa ada unsur paksaan. Hal ini telah sesuai dengan firman Allah dalam surat An-nisa ayat 29. Selain itu seperti yang di ungkapkan Ahmad Sarwat bahwa keuntungan itu harus diketahui jumlahnya.

Kalau jumlahnya tidak diketahui, syirkah tersebut dianggap rusak, kecuali kalau terdapat kebiasaan setempat yang sudah merata yang membolehkan pembagian keuntungan dengan cara tertentu, hal itu boleh dilakukan (Sarwat, 2008:80).

Kerugian yang timbul dengan sistem paron sudah menjadi kebiasaan masyarakat pedukuhan Kadibeso. Maka dari penjelasan diatas risiko kerugian dengan sistem paron diperbolehkan karena sudah menjadi kebiasaan masyarakat tersebut .

Pemilik sawah dengan petani penggarap dalam melakukan kerjasama dengan sistem paron di dasari rasa saling percaya dan kekeluargaan. Biasanya pemilik sawah memercayakan kepada keluarga atau tetangga dekat untuk menggarap sawahnya. Bentuk perjanjian dalam sistem paron dilakukan dengan lisan. Hal ini tidak sesuai dengan Undang-Undang No 2 tahun 1960 tentang bagi hasil pertanian. Meskipun demikian masyarakat Pedukuhan Kadibeso tidak mempersoalkan hal tersebut. Menurut masyarakat Pedukuhan Kadibeso yang terpenting adalah rasa saling percaya dan rasa kekeluargaan.

Sistem paron yang berkembang di Pedukuhan Kadibeso memberikan dampak sosial terhadap ekonomi dan status sosial masyarakat. Dengan adanya pola sistem paron, masyarakat mempunyai pendapatan tambahan sebesar Rp.850.000 Rp.1.500.000 tergantung pada luas sawah yang di garapnya, sehingga dapat membantu memenuhi ekonomi keluarga salah satunya adalah untuk biaya sekolah anaknya.

Sistem paron yang berkembang pada masyarakat Pedukuhan Kadibeso mirip dengan akad mukhabarah. Mukhabarah adalah paroan sawah atau ladang, 
Jurnal Ilmiah Ekonomi Islam, 7(02), 2021, 703

seperdua, sepertiga, atau lebih atau kurang, sedangkan benihnya dari yang punya tanah (Rajdi, 2008:302). Perbedaanya terdapat pada bagi hasilnya jika pada mukhabarah bagi hasil untuk penggarap lebih besar dari pada pemilik sawah.

\section{DAFTAR PUSTAKA}

Abdullah, Boedi dan Beni Ahmad Saebani. 2014. Metode Penelitian Ekonomi IslamBandung:CV pustaka setia.

Afandi,M. Yazid. 2009. Fiqh Muamalah dan Implementasinya dalam Lembaga Keuangan syariah.Yogyakarta: Legung pustaka.

Antonio, Syafi'i. 2001. Bank Syariah dari teori kepraktik. Jakarta: Gema Insani.

Moleong. 2012. Metode Penelitian Kualitatif. Bandung: PT Remaja Rosdakarya.

Negara, Adhe. 2011. Pelaksanaan Bagi Hasil Pertanian Sawah di Desa Bumen Kecamatan Sumowono kabupaten Semarang. Universitas Negeri Semarang.

Rasjid. 2008. Fiqh Muamalah (hukum fiqh lengkap). Bandung: Sinar Baru Algensindo.

sabdodadi.bantulkab.go.id

Sarwat, Ahmad. Fiqh Muamala. 2009. Kamus Syariah.

Sharief, Qorashi, Baqir. 2007. Keringat Buruh (hak dan peran pekerja dalam islam).Jakarta: AlHuda

Sugiono. 2010. Metode Penelitian Bisnis, Alfa eta: Bandung.
Ashari dan Sapta. 2005. Prospek pembiayaan syariah untuk sector pertanian. Pusat analisis social ekonomi dan kebijakan pertanian.

Dimyauddin Djuwairi. 2008. Pengantar Fiqh Muamalah. Yogyakarta: Pustaka Belajar.

http://bps.go.id. Diakses pada tanggal 30 Oktober 2015.

Jayadi, Abdullah. 2011. Beberapa Aspek Tentang Perbankan Syariah, Yogyakarta: Mitra Pustaka.

Khasanah, Umratul. 2009. Implementasi profit and loss sharing (PLS) petani bawang merah ditinjau dari konsep ekonomi islam. Universitas Islam Neger (UIN) Malang.

Mardani. 2012. Fiqh Ekonomi Syariah Fiqh Muamalah. Jakarta: Kencana.

Sutopodan. Adrianus, 2010. Terampil Mengolah Data Kualitatif dengan $N$ vivo, Kencana: Jakarta.

Sukmadinata, Nana Syaodih. 2012. "Metode Penelitian Pendidikan”. Bandung: PT remaja risdakaraya.

Umam, Khotibul. 2016. Perbankan Syariah Dasardasar dan dinamika perkembangan di Indonesia. Jakarta: PT RajaGrafindo persada.

Winarsih, Mulyo. 2008 "Pengaruh Muzara'ah Terhada Pendaatan Masyarakat Desa Kalipasu Kecamatan Slawi Kabuaten Tegal Jawa Tengah".SkriPsi. Program Studi Muamalat Fakultas Syariah dan Hukum, UIN Syarif Hidayatullah Jakarta. 